\title{
Geoecological approach to the design of recreational areas in large cities
}

\author{
Anna Matveevskaya ${ }^{1 *}$, Victoria Pogodina ${ }^{2}$, and Marina Ermolina ${ }^{1}$ \\ ${ }^{1}$ Saint-Petersburg State University, 13B Universitetskaya Emb., St Petersburg 199034, Russia \\ ${ }^{2}$ Saint-Petersburg State University of Industrial Technologies and Design, Russia
}

\begin{abstract}
Life in big cities exacerbates a person's desire to be more often in the bosom of nature, enjoy the peace and beauty of landscapes. The administration of megacities is concerned about the problems of preserving the natural environment and creating within the city limits a network of recreational areas where recreational activities can be organized. In each region, this type of recreation is organized in accordance with the laws adopted in the state. According to geoecologists, the share of recreational areas should be at least $15 \%$ of the total area of the city. So for example the total area of such territories in St. Petersburg is only 6004.4 hectares (which is $4.17 \%$ of the total area of the city). Comparison of the urban map of landscapes and located areas for recreation within the city allows concluding about the unequal representation of each landscape. This should be taken into account when designing new protected areas within the city. In the research, an attempt to generalize the theoretical material in the field of environmental and recreational resource studies is done. Also, a detailed description of recreational opportunities for the rational use of individual components of the city's natural environment is presented. The authors conducted a geoecological analysis of the allocation of recreational areas in large cities. Features of nature that should be taken into account when designing recreational areas in large cities, on an example of St. Petersburg, are noted.
\end{abstract}

\section{Introduction}

The problem of preservation and restoration of the wealth of flora and fauna, unique landscapes is actual. Presently in Russia at state level, conservation and restoration of biological diversity is carried out through the creation of a network of specially protected natural reservation (SPNR) [1]. These are areas of land, water surface, subsoil, with special environmental, scientific, cultural, aesthetic and recreational value, where natural complexes are protected. At the same time, SPNR that are distinguished by outstanding, unique, universal value in terms of science, protection or natural beauty stand out among protected natural areas. Their preservation is necessary not only at the national but also at the world level, as objects of the world natural heritage.

\footnotetext{
${ }^{*}$ Corresponding author: annamatveevskaya@ mail.ru
} 
Since ancient times, tourism has been the most popular use of the most attractive natural areas. Even in the first half of the XIX century, geographers paid attention to undesirable changes in the landscape, resulting from excessive influx of tourists. Annual tourist movements and tourism infrastructure as well as urbanization, industrial development and transport pose a serious threat to the natural environment. Scientists note the devastating impact of tourism on nature. Natural, historical, cultural and socio-economic recreational resources are crucial for the tourism sector of the economy, as the type of tourist and recreational services and specialization of recreational complexes generally depend on their quality and quantity [2]. The recreation industry depends to a great extent on the purity of water, territory, air and, in general, on the ideal state of nature. This type of tourism, as an ecological one, is the closest to the environment in its broadest sense [3].

Analysis of trends in the development of world tourism in the last years of the 20th century. and in the first decade of the 21 st century, shows that among all segments of the tourism industry, eco-tourism is one of the most promising and dynamically developing forms of travel [4]. The main functions of eco-tourism are: improving the quality of life of the local population, promoting environmental protection and conserving biological diversity [5]. The economic benefits of sustainable eco-tourism development can be an incentive for choosing this type of activity as a priority among alternative types of nature management. Russian scientists V. A. Borisov, N. V. Maksakovsky, V. Sycheva $[6,7,8]$ consider ecotourism one of the alternative forms of rational nature management, as this kind of travel is aimed at preserving the natural environment.

The problems that need to be solved in connection with the development of eco-tourism within large cities are most connected with the problems of rational recreational nature management. In different countries, the ways of optimal cooperation of tourism with other activities are determined. The peculiarity of Russia is that, having significant and diverse recreational resources, they are not used to a large extent. St. Petersburg is the third most populous city in Europe. It is the northernmost city in the world with a population of more than one million people. St. Petersburg is the eighth in the world in terms of potential tourism development opportunities in the UNESCO ranking [9]. The city is the third in the world by the number of architectural monuments and museums after Paris and Rome. Capacity, uniqueness and diversity of cultural resources to some extent reduces the interest of visitors to its natural attractions. However, they are vitally important for the inhabitants of the metropolis. The purpose of this study is to find ways of optimal development of eco-tourism within the SPNA of St. Petersburg. Research hypothesis: the process of using SPNA of St. Petersburg as destinations for ecological excursion and tourism activities will be optimal if the landscape features of these areas are taken into account, the use of modern world and domestic experience in the designing of conditions for the stay of recreants and excursionists.

\section{Materials and Methods}

Conditions for the organization of eco-tourism are available on the territory of St. Petersburg. The Northern districts of the city are located within the Karelian isthmus. In the mid-seventies of the last century, scientists actively discussed the creation of a national park here, in which urban areas would be included. However, the intentions remained unfulfilled. In the early $90-$ ies of XX century, the proposal to organize a natural park along the northern shore of the Gulf of Finland was discussed [10]. Probably, political and economic problems did not allow the city to carry out this important project.

SPNA of different statuses and ranks are available on the territory of the city. Nature reserves and natural monuments are located here. They allow organizing visit by tourists traveling with cognitive, scientific, educational and recreational purposes. Recreational programs can be combined with other activities, such as sports, health, interest classes, etc. 
The law of St. Petersburg approved the modern system of the city's SPNA in 2013. The Total area of fifteen existing SPNA in St. Petersburg is 6140 hectares. This is more than 4\% of the total area of the city. Most of them are close to the coast of the Gulf of Finland. Comparison of the urban map of landscapes and protected areas, located within these limits, leads to the conclusion about the unequal representative representation of each landscape. This should be taken into account when designing new SPNA within the city limits. Kurortniy city district will take the first place in terms of the number and SPNA's area. The administration plans that SPNA will occupy 1/10 of Kurortniy city district's area by 2025 .

The Directorate of St. Petersburg's SPNA does a lot to inform citizens about the possibilities of visiting these territories during one-day trips. However, it is necessary to pay more attention to advertising such opportunities. For this purpose, it is possible to distribute information materials about protected areas more intensively and more variously, more often organize promotional tours for employees of tourist enterprises, which could be interested to potential tourists. Complementary theoretical and experimental methods were used to achieve the goal, to solve the tasks set in the work and to test the research hypothesis. Theoretical methods are the analysis of literature and electronic resources on the topic of research, the method of expert assessments. Experimental methods are questioning, observation, organization of eco-excursions.

\section{Results}

The analysis of the possibility of using SPNA for recreational activities showed that nature monuments can only be of interest as sightseeing objects. For eco-tourism, areas such natural reserves as "Western Kotlin", "Sestroretsk swamp", "Lake Shchuchye", "Gladyshevsky" can represent [11]. It is necessary to develop a development strategy for each of them in creating conditions for the organization of eco-excursion and tourist activities within these reserves. In any case, it is necessary to create a tourist infrastructure for the success of the organization of this activity.

The Russian Federal Law on SPNA allows regional authorities to establish local environmental laws and regulations, based on which to create new SPNA. For large cities, especially for St. Petersburg, it can be the status of urban conservation area for recreational purposes. Perhaps, it is necessary to return to discussion of the organization within Kurortniy city district of this type of SPNA as a natural and recreational park "The Baltic Fairy Tale". The development of this type of SPNA will take into account the history and character of nature management within the city's lands. The creation of a natural park will bring not only environmental but also an economic benefits, namely, the creation of additional jobs, financial revenues to the municipal and regional budgets. In addition, the competitiveness and investment attractiveness of Kurortniy city district will increase due to the implementation of this project.

The main idea of the creation of "The Baltic Fairy Tale" in Kurortniy district of St. Petersburg is the rehabilitation of landscapes, biodiversity conservation area, development of recreational tourism, environmental education of visitors to the park. Based on the results of the situational analysis, it is possible to assess whether the project has internal forces and resources to make the most of the available resources, to realize the existing potential and to counter threats, and what weaknesses need to be addressed as soon as possible (Table 1). Thus, despite a number of negative factors identified as a result of SWOT analysis, it can be concluded that the tourist potential of the project area of a natural park can be estimated as high. The territory possesses natural, historical, cultural, tourist, as well as labor and material resources, attractive for tourists, for the full realization of the tourist-recreational and nature protection potential of the natural park. 
Table 1. Assessment of tourist and recreational potential of the developed natural park "The Baltic Fairy Tale" with SWOT-analysis

\begin{tabular}{|c|c|}
\hline Strenghts & Weaknesses \\
\hline $\begin{array}{l}\text { - developed transport infrastructure; } \\
\text { - convenient geographical location; } \\
\text { - an opportunity to attract more tourists, given the close } \\
\text { location of the Park to the Leningrad Region and Finland; } \\
\text { - the possibility of starting the Park's operation even with } \\
\text { a minimum of built } \\
\text { - universality - the Park is designed for any type of } \\
\text { recreation, active, passive and for a therapeutic and } \\
\text { recreational type of rest; } \\
\text { - the Park is designed for visitors of different age } \\
\text { categories; } \\
\text { - a variety of natural resources and places of interest } \\
\text { contribute to attracting tourists; } \\
\text { - ecological education of the population; } \\
\text { - new jobs for residents of the district; } \\
\text { - improvement of registration system and monitoring of } \\
\text { arriving tourists. }\end{array}$ & $\begin{array}{l}\text { - increase of traffic flow to the district; } \\
\text { - insufficient public awareness of the Park; } \\
\text { - difficulties in protecting nature from factors } \\
\text { related to tourism and poaching; } \\
\text { - difficulty in determining the appropriate } \\
\text { balance between environmental protection and } \\
\text { tourism development in the allocation of the } \\
\text { Park's resources; } \\
\text { - financing of natural parks in Russia } \\
\text { unstable now. }\end{array}$ \\
\hline Opportunities & Threats-analysis \\
\hline $\begin{array}{l}\text { - development of a natural park as a new tourist center of } \\
\text { St. Petersburg; } \\
\text { - the potential for the development of promising types of } \\
\text { tourism that meet the needs and demands of the modern } \\
\text { tourism market; } \\
\text { - opportunities for businesses to receive revenues from } \\
\text { local resources and develop services; } \\
\text { - increase in Park's attractiveness due to effective } \\
\text { advertising; } \\
\text { - increase of the Park's competitiveness due to the } \\
\text { organization of new tours, excursions, routes. }\end{array}$ & $\begin{array}{l}\text { - lack of resources to receive even more } \\
\text { visitors; } \\
\text { - protection of biodiversity may become the } \\
\text { secondary after tourism; } \\
\text { - the increasing flow of tourists increases the } \\
\text { risk of forest fires, poaching, crime; } \\
\text { - environmental vandalism in the Park, sale of } \\
\text { land for the construction of cottages and } \\
\text { industrial logging in the SPNA; } \\
\text { - changing the needs and preferences of } \\
\text { potential consumers of the Park's tourist } \\
\text { services. }\end{array}$ \\
\hline
\end{tabular}

The presence of a significant recreational and tourist potential determines the need to create and develop a system of recreation and tourism institutions that will contribute to attracting additional funds to the environmental protection system. So the construction of camping sites, ecological paths, guest houses on the territory will allow involving the population in the ecotourism process.

The main objectives of the territorial planning project for a specially protected area of regional importance - the natural park "The Baltic Fairy Tale" are:

1. Achievement of the goals and objectives of the natural park "The Baltic Fairy Tale" in the process of territorial planning: protection and restoration of natural resources, environmental education and study of unique natural complexes.

2. Realization of recreational and tourist potential of the territory in accordance with the principle of sustainable development.

3. Creation of conditions for integrated development of the territory of the natural park by establishing functional zones, zones with special conditions for use of territories, zones of planned placement of capital construction objects for state needs, including engineering, transport and social infrastructure [12].

In order to achieve the set goals of the territorial planning of the specially protected area of regional importance, the nature park "Baltic Fairy Tale" creates the conditions for the following tasks:

1. Realization of bodies of the St. Petersburg government' powers in the field of tourism, recreation and sports; 
2. Creation of conditions for increasing the investment attractiveness of the territory by implementing measures to develop transport, engineering, recreational and tourist infrastructures, stimulating recreational construction, business activity, production, trade, science, tourism and recreation;

3. Creation of conditions for sustainable development of the Kurortniy district of St. Petersburg through the development of natural and recreational potential of the territory of the natural Park "Baltic fairy tale" on the principles of rational nature management and environmental safety for the population, protection of natural complexes and objects of special environmental, scientific, cultural, aesthetic and recreational importance.

4. Establishment of an environmental monitoring system.

5. Creation of the necessary engineering and transport infrastructure system.

6. Creation of a system of protection against natural disasters and emergency situations of natural and man-made character.

7. Formation of ecologically clean, well-maintained and comfortable zone to accommodate objects of sport, tourism and recreation facilities.

8. Formation of investment-attractive functional zoning of the territory [13].

The projected natural Park is located in the North-West of St. Petersburg in the Kurortniy district on the Northern coast of the Gulf of Finland. All settlements (except Zelenogorsk and Sestroretsk), will fall into the natural Park. In the same way, the natural Park will unite the already existing SPNA of this city's district: the "Sestroretsky swamp", "Lake Shchuchye", "Levashovsky forest", "Komarovsky Bereg". The total area of the Park will be 20 thousand hectares.

The planned natural Park should be divided into four functional areas:

- Recreational zone is designed for active recreation, accommodation of tourist infrastructure, recreation centers.

- "Regulated tourism" zone. These are the locations of interesting natural and historical sites. In such areas it is necessary to create conditions for minimizing damage from recreational use of the territory.

- The administrative and economic zone is designed for the location, construction and operation of facilities necessary to ensure the protection, maintenance and use of the natural Park in accordance with its goals and objectives.

- The agro-economic zone is intended for the local residents to carry out traditional economic activities.

The natural Park should satisfy the needs of visitors, provide an opportunity for passive and active recreation, physical and psychological rehabilitation, obtaining new knowledge, and contribute to the formation of careful attitude to nature. For this, the Park should provide a full range of services, from accommodation to creating conditions for any kind of recreation. At the same time, the entire infrastructure of the Park must be in harmony with nature and the surrounding landscape, to be as safe as possible for the environment, to minimize the anthropogenic impact on nature.

To ensure the activity of the natural Park, it is necessary to build visit centers and information points, cottages, campsites. Need to equip tourist camps, schools and trails, water and walking routes, car parks, observation platforms, boat stations. Information boards and signs should be installed throughout the Park.

Creation of visit-center is one of the main directions of ecological and educational activity of natural parks. They should become an active base of ecological and educational work with the population and visitors to SPNA. The most suitable place for the construction of the visitcentre is the village of Solnechny, where all the necessary conditions exist: the location near the geographical center of the Park; the infrastructure of tourism business, the availability of all types of transport, the proximity of the coast of the Gulf of Finland.

The infrastructure of the visit center complex consists of: 
- Visit-center

- Mini-Hotel

- Summer café

- Houses where master classes on folk crafts are held

- $\quad$ Mini-Zoo

- Playground

The visit-center is a place where visitors of the Park receive information about SPNA, as well as related recreational services. Permanent and temporary exhibitions are organized, classes with children are held, lectures are read. Also, the visitor can get advice about the main attractions of the Park and the possibilities of living in the protected area, make an appointment for a tour, visit a cafe, try the eco-friendly products produced in the Park, buy brochures, maps and souvenirs. The visit-center is often the starting point from which ecological trails originate.

Visit-center project is:

Basement. This room is provided for service and technical purposes, storage of items issued for rent (tourist and safety equipment for water and snowmobile trips).

Information Desk is on the first floor. Here the visitor can get advice on excursions and master classes provided by the visit-center, as well as environmental, educational and interactive excursions to the natural and cultural attractions of the natural Park; get rental of the required equipment; get acquainted with the price list for tourist services; learn about the possibility of living in the Park; purchase or book the necessary services.

- Visit-center office. There will be offices of various services: Department of water fauna, Department of environmental education, forest Department, as well as a tourist center. Also on the first floor will be located office space for the staff of the visit-center.

- Gift shop. Souvenirs with the symbols of the natural Park, presented by the artistic creations of local artists, books, videos about the natural Park, postcards calendars will be sold here. Wardrobe and dressing room are here. On the second floor the main exposition of the visit-center is presented. It consists of four thematic sections: "natural heritage", "cultural heritage", "nature assistance", "threats of natural Park".

The section "natural heritage" is the biggest exposition. The expositions are made with the use of modern and natural materials, which in combination with lighting devices and components of sound reproduction, creates an atmosphere of presence of real wildlife. The Kurortniy district is rich in water resources, so the exhibition hall presents several exhibitions devoted to rivers, lakes, swamps and the Gulf of Finland.

- The hall of "cultural heritage" creates an idea of the historical stages of development of the region: the Neolithic sites near lake Sestroretsky Razliv, the numerous wars between Russia and Finland for this territory, the contribution of Peter the Great to the development of this city's district.

- Section "nature assistance" represents visitors what the Park's employees do. On the stands are photos showing the current work of the department of environmental education and the scientific department.

- The last section "threats to the natural Park". The stands contain information and photos telling about fires and debris and poaching. These are the most serious threats to the welfare of the plant and animal life of the reserve. On the third floor the class of children's ecological school is located. The purpose of the school: environmental education, improving the culture of relationships with nature, the development of environmental standards of behavior in the natural environment, education of a sense of personal responsibility of each for the state of the environment. It contains environmental games, computer programs for the development of children's cognitive abilities. On the basis of the school there are various trips and excursions to the most beautiful places of the natural Park. A small hall for 20 people with a multimedia installation and a stage is located next to the children's environmental 
school. In addition to comfortable viewing of various films about the Park and environmental issues, the opportunity for mini-conferences and seminars and children's environmental performances is provided here.

In the rest room there is a large panoramic window. It allows visitors to get in touch with nature visually without leaving the visit-center. Comfortable mini-hotel, designed for seven rooms is located next to the building of the visit-center. Four double rooms with living room, bedroom and sanitary unit and three single. On the ground floor of the hotel is a restaurant with Russian cuisine, where you can spend time with friends and family or organize a business meeting. On the territory of the complex in the summer months the cafe will work. Here visitors can enjoy dishes from organic products. The cafe consists of a summer terrace in the form of a tent, and the greenhouse adjacent to the veranda, where fruits, berries and vegetables are grown. If desired, every guest of the cafe will be able to choose ingredients from the garden for their meals, as well as to purchase them. In order to make your stay in the complex of the visit-center more interesting, on the territory of the complex there are houses, where master classes on different crafts are held: weaving, felting of wool, composition of straw and poplar down, pottery, floristry, macramé and knitting, decorative flowers, a young naturalist.

There is a small Zoo on the territory of the complex. In the Zoo there are representatives of the local fauna: squirrels, hares, foxes, moose and so on. Animals can be fed from the hands - special food sets are sold directly in the Zoo. Also here are the enclosures of animals in trouble and temporarily in the Zoo. There is a small children's Playground near the Zoo. On the territory of the designed natural Park, tourists can be located in guest houses, camping grounds, on tourist parking. In the first run of the natural park, it is planned to allocate three sections of the territory for the construction of guest houses, where tourists will have the opportunity to spend several days in picturesque countryside with the preserved natural and cultural environment. Also in the territory of the Park, it is planned to equip the territory for the creation of camping and tourist parking. To accommodate campers places under tents and fire places are equipped, tables with awnings are placed, toilets, showers, places for cooking are available. Drinking water, firewood are provided, rental of tourist equipment is carried out.

Additional infrastructure of the natural Park is:

- Rope Park "High forest" located in the Zelenogorsk city. Visitors overcome all kinds of obstacles located between the trees at a height of one to twenty meters. All routes vary in complexity and are designed for passage, both adults and children.

- Parking for vehicles at the entrance to the Park, in places of the greatest concentration of people.

- At the Gulf of Finland on one of the parking lots to install the screen for watching movies in forty auto seats, which will be staggered.

- Bicycles, tents, sleeping bags can be purchased in the houses for rent. On the shore of ponds boats and fishing rods are provided.

- Information points are established to provide information to visitors. They should be located at the entrance to the Park and in places of mass visiting.

- Information boards should be located at the entrance to the Park on the main roads, in all settlements where there is no visit-center or information points, in recreational centersplaces of mass tourist visits, as well as in places of the beginning of ecological trails, pedestrian and water routes start, on the most important tourist sites.

- Laying tracks for a drive on bicycles, rollers, skateboards etc. Roads should take place in crowded places.

- Observation towers are created for observation. It is planned to build three observation towers. In the summer months, visitors to the observation tower, in the dark, will be able to watch the stars and planets, thanks to a mobile observatory, which will provide staff of the 
Park. This does not require special knowledge in astrology, as the telescope will be able to find any objects from its base automatically.

\section{Discussion}

The policy of organizing recreation within modern urban SPNA raises many questions and comments among many residents of St. Petersburg. The main problem should be recognized as the deterioration of opportunities for recreation in the traditional metropolitan areas after the organization SPNA. Apparently, the designers did not take into account the recreational traditions that were formed for at least one and a half hundred years, when creating a modern network of urban SPNA.

The necessity and importance of establishing a network of SPNA within the metropolis is not in doubt. But the status of the created nature reserves implies, for the most part, prohibitions and restrictions for the organization of recreational activities. You cannot just put barriers on long-established asphalted roads for cars, used by citizens for decades to travel to places of short-term rest. It is necessary to allow travel by charging a fee for the service (this will be an income item for environmental protection activities and infrastructure development for SPNA). While in front of most of these barriers with security booths at the borders of SPNA there are no parking zones. Potential recreants are forced not just to leave their cars unattended, but also to look for a parking place in the forest, thus destroying the plant cover on significant areas before entering. In Russia, there are natural reserves, within which transportation is allowed [14]. St. Petersburg must adopt this experience. It is impossible to forbid people to use campfires which became traditional for camp life. It is necessary to equip stationary places for fireplaces with the necessary equipment. Leaving vehicles at the borders of SPNA, potential recreants are forced to return several times to transfer folding light furniture (tables, chairs, etc.), equipment for activities with children, sports games to the chosen place for recreation. Unfortunately, there is no infrastructure on such territories, which is necessary not only for recreation, but also, for example, for conducting classes with schoolchildren or students visiting protected areas with ecological and educational purposes (areas where equipment for organization of nature-oriented observations and research can be placed, gazebos with benches and tables are so necessary in specific climatic conditions of the North-West of Russia). It's typical situation for all SPNA of St. Petersburg.

\section{Conclusions}

The General plan of St. Petersburg provides for the organization of a system of SPNA in order to improve the environmental protection. New SPNA will be created before 2025. Some of them, for example, "Levashovo forest", "Coastal ledge Serovo", "Puhtolova mountain" can be examples of new types of SPNA, that solve both environmental and recreational tasks.

Natural parks of different profiles can be created on the territory of the city. From the point of view of modern scientific approaches, the most promising forms of natural parks should be parks which provide:

- Zones of scientific and educational importance (for scientific ecological and landscape researches with arrangement of ecological trails and routes),

- Recreational zone (with construction of walkways, stops, tent camps and parking for tourists, mini-camp sites, tourist sites); 
- Sports tourist parks (with specially organized territories, including facilities and areas for training and amateur qualifying tourism, as well as educational and sports tourist eventstourist rallies, competitions, seminars, etc.).),

- Fishing and hunting parks (with specially designated territories for carrying out hunting and amateur fisheries regulated by licenses, as well as ecological, zoological, ichthyological research and activities);

- Water parks (focused on water areas and territories suitable for the development of water tourism-yachting, swimming, boating, relaxing on the beach, etc.)

- Agricultural parks, and in the version of St. Petersburg-natural - historical dacha zones (with dedicated special areas designed for agricultural activities, exhibiting its tourists, as well as the creation of country museums, ethnic museums, museums demonstrating the achievements of modern science and technology in the arrangement of dacha farms, not harmful to the natural environment) [15].

In any case, SPNA should have visit centers equipped in accordance with international experience and modern requirements for the organization of eco-excursion and tourism activities. Eco-tourism can and should become for the economy of St. Petersburg not only an urban, but also a Federal specialization, with a correctly built policy based on the integrated use of tourism and reclamation resources, taking into account all conditions that can contribute to the development of recreation.

\section{References}

1. Federal'nyy zakon «Ob osobo okhranyaemykh prirodnykh territoriyakh» 14.03 .1995 (redaktsiya ot 29.07.2017)

2. S. Kaffashi, A. Radam, M. Shamsudin, M. Yacob, N. Nordin. For. 6(7) (2015)

3. E. Kolobovskiy, Ekologicheskiy turizm i ekologiya turizma (2011)

4. R. Buckley. Front. in Ecol. and Envir. 11, 8 (2013)

5. C. J.LeónaJavierde, L. E.Arañaab, M. M.Gonzáleza, Ecol. Econ. 118 (2015)

6. V. Borisov, L. Belousova, A. Vinokurov, Okhranyaemye prirodnye territorii mira (2005)

7. N. Maksakovskiy, Natsional'nye parki v urbanizirovannykh rayonakh Rossii (2007)

8. V. Sycheva, Znachenie natsional'nykh parkov v razvitii turizma (2007)

9. A. Baranov, E. Bogdanov, N. Vereshchagina, I. Filippova, Pamyatniki Vsemirnogo prirodnogo i kul'turnogo naslediya Rossii v sisteme turizma (2017)

10. D. Sevast'yanov, E. Korostelev, Vest. San-Pet. Gos. univ. Ser. 7. 1 (2005)

11. A. Matveevskaya, V. Pogodina, Geography of tourism of the European part of Russia. In: Geography of tourism of Central and Eastern Europe countries (2017)

12. V. Chizhova, Rekreatsionnye landshafty: ustoychivost', normirovanie, upravlenie (2011)

13. R. Bolgov, M. Ermolina, N. Vasilyeva, Intern. Conf. Proc. Ser. 3 (2016)

14. Yu. Gorbunov, A. Demidov, Osobo okhranyaemye prirodnye territorii $R F$. Botanicheskie sady i dendrologicheskie parki (2012)

15. V. Pogodina, I. Filippova, Geografiya turizma. (2016) 